\title{
Knowledge and Prevalence of Supplements Use
by Brazilian Resistance Training Practitioners Before Coronavirus Outbreak
}

\author{
Rodrigo Luiz Vancini (iD' \\ Weverton Rufo-Tavares (I) \\ Hudson Renato de Paula \\ Oliveira $(\mathbb{D})^{\prime}$ \\ Ricardo Borges Viana $\mathbb{D}^{2,3}$ \\ Marilia dos Santos Andrade (iD) 4 \\ Beat Knechtle (iD ${ }^{5}$ \\ Pantelis Theodoros \\ Nikolaidis ${ }^{6}{ }^{6}$ \\ Paulo Gentil (iD ${ }^{7}$ \\ Claudio Andre Barbosa de \\ Lira $\left.{ }^{7}\right)^{7}$
}

'Centro de Educação Física e Desportos, Universidade Federal do Espírito Santo, Espírito Santo, Brasil; ${ }^{2}$ Escola Superior de Educação Física e Fisioterapia do Estado de Goiás, Universidade Estadual de Goiás, Goiânia, Brasil; ${ }^{3}$ Faculdade Estácio de Sá, Goiânia, Departamento de Educação Física, Goiânia, Brasil; ${ }^{4}$ Departamento de Fisiologia, Universidade Federal de São Paulo, São Paulo, Brasil; ${ }^{5}$ Medbase St. Gallen Am Vadianplatz, St. Gallen and Institute of Primary Care, University of Zurich, Zurich, Switzerland; ${ }^{6}$ School of Health and Caring Sciences, University of West Attica, Athens, Greece; ${ }^{7}$ Setor de Fisiologia Humana e do Exercício, Faculdade de Educação Física e Dança, Universidade Federal de Goiás, Goiânia, Brasil
Correspondence: Beat Knechtle Facharzt FMH für Allgemeinmedizin, Medbase St. Gallen Am Vadianplatz, Vadianstrasse 26, St. Gallen, 900I, Switzerland

Email beat.knechtle@hispeed.ch
Introduction: The use of dietary supplements and ergogenic aids (DSEA) is popular among physical activity enthusiasts. Particularly, resistance training (RT) practitioners represent important DSEA consumers due to its easy access and the appeal of claims related to muscle hypertrophy, aesthetics, and physical performance improvements.

Methods: Our aim was to study knowledge, prevalence, and profile of DSEA used by Brazilian recreational RT practitioners. For this, RT practitioners of both sexes $(n=129$, female $=58$ and male=71) answered a paper-based questionnaire. The questionnaire was specifically created for the studied population to assess different aspects of the DSEA used and sociodemographic variables.

Results: Seventy-seven percent of the participants ( $n=99)$ declared that they had already used DSEA. The majority (53\%) searched the internet to obtain information about DSEA. Whey protein $(66 \%)$ was the most used followed by branched chain amino acids $(48 \%)$.

Conclusion: The use of DSEA, before coronavirus outbreak, was popular among RT practitioners; protein and amino acids were the most used DSEA. Most users used internet to obtain information about DSEA. The results suggest the need for appropriate attitude and guidance by health professionals who deal with this population, especially dietitians, nutritionists, and physical training professionals in order to promote best and security practices.

Keywords: nutrition, supplements, gyms, resistance training, ergogenic

\section{Introduction}

Dietary supplements and ergogenic aids (DSEA) are easily available and widely used to improve physical performance. ${ }^{1-3}$ Previous studies showed that more than three million people in the US use or have used DSEA., ${ }^{4,5}$ DSEA is usually consumed for obtaining aesthetic and physical results and is heavily influenced by media advertising. ${ }^{6}$ Athletes and exercise enthusiasts are the most frequent consumers; ${ }^{1-3}$ including recreational exercisers who aim health and/or aesthetic outcomes. $^{7-9}$ As for athletes, in many cases, the use of DSEA aims to increase dietary protein intake (usually $\geq 1.2$ grams of protein $/ \mathrm{kg} /$ day), to improve physical recovery and increase the adaptive and anabolic responses of skeletal muscle to physical training. ${ }^{10}$ Regarding physically active individuals, the most popular reasons for using nutritional supplements are to increase muscle size and strength and/or prevent diseases. ${ }^{11-13}$

Some authors compared sociodemographic characteristics (age, sex, region, education, income, and level of physical activity), specific exercise programs and 
sports practiced between DSEA users and non-users, and found significant differences in motivators, knowledge level, DSEA types, and profiles. ${ }^{4,9,14-17}$ In addition, studies found that older participants more frequently ingested DSEA to prevent diseases and younger participants did it for aesthetics and physical performance; men made used DSEA more frequently than women and people who used protein supplements also consumed greater amounts of protein-rich foods in the diet when compared to those who did not consume DSEA; $;^{4,9,10,14-17}$ The most popular DSEA used by gym practitioners from different countries (US., UK., Italy, Canada, and Switzerland) are protein supplements. ${ }^{15}$ Knapik et $\mathrm{al}^{18}$ showed that elite athletes used DSEA more frequently than their non-elite peers, DSEA use was similar between men and women, and a higher proportion of athletes used DSEA compared to the general population.

Previous studies (before the 2019 coronavirus pandemic) have shown that protein supplements are the most widely taken by gym attendees. ${ }^{4,9,16}$ However, physically active people, in general, do not need additional nutrients and DSEA, as long as they have an adequate diet. ${ }^{19,20} \mathrm{It}$ should be noted that some DSEA contain high concentrations of ingredients that are potentially harmful to health and some potentially toxic ingredients. ${ }^{21,22}$ Moreover, many DSEA do not correctly report the amounts and quality of the components listed on the labels, as well as whether their composition contains substances that could cause doping. ${ }^{21,22}$ Despite this, the use of DSEA has only increased and this market is highly profitable. ${ }^{19,20}$

Another apparent problem is that many DSEA users who attend gyms obtain information about supplements from unqualified sources and professionals, which is an additional risk. ${ }^{1,9}$ For example, Mettler et $\mathrm{al}^{23}$ showed that there is a high prevalence of DSEA intake among Swiss gyms attendees and this use is associated with a low quality information on safety and risks. Based on this, it might be important that health professionals (preferably dietitians) develop education programs directed to guide the best practices for DSEA use. Wardenaar et $\mathrm{al}^{24}$ demonstrated in an expressive sample of female and male Dutch elite and sub-elite athletes that dietary counseling could result in more accurate choices regarding DSEA use with a focus on improving physical performance, physical recovery, and of health status.

Thus, our aim is to evaluate the knowledge, prevalence, and use profile of DSEA among Brazilian recreational RT practitioners. Despite the existence of much information on the use of DSEA among athletes, ${ }^{25-27}$ there is still little information on the intake of supplements and the profile of Brazilian recreational RT practitioners. ${ }^{1,9,28}$ which is an important gap, since Brazil is the second country with most gyms in the world. In fact, although it is known that the use of DSEA is a widespread practice among exercisers, few studies have been conducted in specific regions of Brazil. Furthermore, data collected before the coronavirus pandemic (2019) became interesting to be disseminated.

\section{Materials and Methods}

\section{Participant's Characteristics and Ethical Approval}

Our research was a single-phase cross-sectional study that involved a convenience sample $(\mathrm{n}=129)$, chosen at random by personal invitation among RT practitioners from gyms from different regions of the State of Espírito Santo (Southeastern region of Brazil). To participate in the study, people had to regularly practice RT (at least twice a week), be over 18 years old, and be free from apparent cognitive limitations. Data were collected and analyzed in the 1st and 2nd semester of 2017, that is, two years before the coronavirus pandemic. People from different cities in the State, representing the main regions and with the highest population density, participated in the study: Vitória $(n=32)$, Vila Velha $(n=31)$, Serra $(n=33)$ and Cariacica $(n=33)$ As far as possible, samples were equalized to be more homogeneous and, therefore, to present less biased data. The aim was to include people with different education levels and socioeconomic status from different regions. Gym visits were carried out randomly and on different days of the week and at different times (morning, afternoon, or night). All RT practitioners included in this study were approached, before or after training, to complete the questionnaire in full. The sample size was chosen based on studies that evaluated the use of DSEA by RT practitioners. To achieve the aims of this research, a questionnaire was designed - which was evaluated by a panel of experts and with different backgrounds in the field. To choose the most relevant questions, we studied the literature in the area (by PubMed) as well as practical and market aspects of the DSEA (by Google search) that we considered important, so that the questionnaire was attractive and had greater ecological validity. DSEA inclusion in the questionnaire was performed based on scientific and market research. The questionnaire was applied to 
assess different aspects of DSEA use (type, prevalence, frequency, use profile, and knowledge level) and socioeconomic and demographic variables. Questionnaire questions were designed to assess qualitative and quantitative aspects of DSEA use, with a focus on closed questions (yes or no, true or false, and/or quantity) and that assessed frequency of DSEA use and level of knowledge. The main researcher remained at the place where the questionnaire was applied to clarify any doubts that might arise. In addition, the importance of the veracity of the information provided was emphasized in order to minimize the effect of the subjectivity of the answer to the questionnaire. All participants signed an informed consent form. All procedures were approved by the Research Ethics Committee of the Federal University of Espírito Santo (Certificate of Presentation of Ethical Appreciation - CAAE: 63228215.1.3001.5505).

\section{Questionnaire}

An instrument was designed, created, and applied to assess sociodemographic profile and knowledge about DSEA. The instrument was composed of variables and information related to physical activity and DSEA use (for more information, in the same link, see Supplementary Material 1 and 2). For the socioeconomic classification, a specific questionnaire was used. ${ }^{29}$ The instrument used was validated to define social class through the assessment of possession of items, such as tv, computer, radio, bathroom at home, car, maid, washing machine, and refrigerator and their respective quantities and education level of the head of the family.

\section{Statistical Analysis}

Pearson's chi-square test was used to verify association between variables. The level of significance adopted in all analyzes was set at alpha $=0.05$ and $95 \%$ confidence intervals were calculated. All data analyses were performed in the IBM SPSS v24 (IBM Corp., Armonk, NY, USA). Data are presented as absolute and relative frequency unless otherwise stated.

\section{Results}

\section{RT Participants Characteristics}

Tables 1 and 2 showed the general characteristics of RT participants $(\mathrm{n}=129)$. Participants exercised $5.0 \pm 1.0$ times/week and $96.0 \pm 36.0$ minutes/day. As for the modalities practiced, $46.5 \%(\mathrm{n}=60)$ practiced only $\mathrm{RT} ; 42.6 \%$
Table I Characteristics of Participants, $n=129$ (Female/Male $\left.=58 / 7 I^{*}\right)$

\begin{tabular}{|l|l|l|}
\hline Variables & $\begin{array}{l}\text { Mean (Standard } \\
\text { Deviation) }\end{array}$ & $\begin{array}{l}\text { Minimum- } \\
\text { Maximum }\end{array}$ \\
\hline Age (years) & $30.1(8.8)$ & $18.0-60.0$ \\
Body mass $(\mathrm{kg})$ & $70.8(14.0)$ & $47.0-128.0$ \\
Height $(\mathrm{cm})$ & $170.0(0.1)$ & $150.0-190.0$ \\
Body mass index $\left(\mathrm{kg} / \mathrm{m}^{2}\right)$ & $24.5(3.4)$ & $18.0-37.4$ \\
\hline
\end{tabular}

Notes: $\mathrm{n}$ : sample size. ${ }^{*}$ Absolute number of female and male participants, respectively.

$(\mathrm{n}=55)$ practiced another sport in addition to RT; $9.3 \%$ $(n=12)$ practiced RT plus two modalities, and only $1.6 \%$ $(n=2)$ practiced three or more modalities in addition to RT.

\section{DSEA Profile Use}

Most RT participants declared they had already used DSEA. Of the 99 subjects who declared they had already used DSEA, 77 were current users $(60 \%$ of the total sample). Most participants $(34.9 \%, \mathrm{n}=45)$ were from social class B2 according Brazilian classification, 65\% ( $\mathrm{n}=84)$ were single, and 39\% $(n=50)$ had completed high school. Table 3 below shows the participant's sociodemographic profile.

The majority $53 \%(n=68)$ of the participants searched in the internet to obtain information about DSEA and 39\% $(n=50)$ through dietitian or nutritionist, 30\% ( $\mathrm{n}=39)$ obtained information from friends, $18 \%(\mathrm{n}=23)$ on television, $17 \%(\mathrm{n}=22)$ from the supplement store staff, $16 \%$ $(n=20)$ at college, $5 \%(n=7)$ with a physical education professional, $3 \%(\mathrm{n}=4)$ in Journalistic fonts, $2 \%(\mathrm{n}=2)$ on the radio, $2 \%(\mathrm{n}=2)$ in scientific fonts, $1 \%(\mathrm{n}=1)$ in street

Table 2 Profile of Physical Activities Performed by the Participants, $n=129$

\begin{tabular}{|l|l|}
\hline Practice of Physical Activity & $\%(\mathbf{n})$ \\
\hline Experience (years) & \\
$<$ I & $27(35)$ \\
I-2 & $13.2(17)$ \\
$2-3$ & $15.5(20)$ \\
$3-4$ & $5.4(7)$ \\
$\geq 4$ & $38(50)$ \\
\hline Exercise modalities & \\
Only resistance training (RT) & $46.5(60)$ \\
RT plus 2 other modalities & $9.3(12)$ \\
RT plus other 3 modalities & $42.6(55)$ \\
RT plus $\geq 3$ other modalities & $1.6(2)$ \\
\hline
\end{tabular}


Table 3 Participant's Socioeconomic and Demographic Profile, $n=129$

\begin{tabular}{|l|l|}
\hline Variables & $\%(\mathbf{n})$ \\
\hline Socioeconomic class & \\
AI & $2.3(3)$ \\
A2 & $14(18)$ \\
BI & $23.3(30)$ \\
B2 & $34.9(45)$ \\
CI & $20.2(26)$ \\
C2 & $5.4(7)$ \\
\hline Marital status & \\
Single & $65(84)$ \\
Married or stable relationship & $29(37)$ \\
Divorced & $5(6)$ \\
Widowed & $2(2)$ \\
\hline Educational level & \\
High school (complete) & $39(50)$ \\
Higher education (incomplete) & $26(33)$ \\
High education (complete) & $18(23)$ \\
Specialization & $9(12)$ \\
Master's degree & $1(1)$ \\
PhD & $1(1)$ \\
\hline
\end{tabular}

advertising, and $6 \%(\mathrm{n}=8)$ never obtained information on the topic.

Seventy nine percent $(n=102)$ of the participations alleged in DSEA effectiveness; 9.3\% $(n=12)$ did not trust and $11.6 \%(n=15)$ did not know how to position themselves. Regarding security, 54.2\% $(n=70)$ believed in security, 29.4\% $(n=38)$ did not trust and 16.3\% $(n=21)$ did not know how to answer.

Among DSEA users $(n=99) 50.5 \%(n=50)$ used up to two types of DSEA, 27.2\% $(n=27)$ used three or four types, and $22.2 \%(n=22)$ used five or more types. Whey Protein was the most used DSEA, being used by $66 \%$ of the users $(n=66)$; followed by branched chain amino acids (BCAA) 48\% $(n=48)$. Table 4 shows the types of DSEA used by the sample of RT practitioners evaluated $(n=129)$. It is important to note that the participant could choose more than one type of DSEA.

Among those who claimed to use DSEA, 36.3\% $(n=36)$ stated that the dietitian was the professional responsible for the prescription, $23.2 \% \quad(n=23)$ selfprescribed, $24.2 \%(n=24)$ ingested under the guidance of a Physical Education Professional/Personal trainer, 9.1\% $(n=9)$ for medical advice, 3\% $(n=3)$ claimed to be the seller of the supplement store who prescribed it, 3\% $(n=3)$ under the guidance of a training colleague and $1 \%$ $(n=1)$ under the guidance of a beautician. In addition, of the 99 individuals who reported having used supplements and/or ergogenic aids $89 \%(n=88)$ reported never having experienced side effects.

It was observed that $6.2 \%(n=8)$ answered that they visited DSEA stores once a week or more frequently; $36.4 \%(n=47)$ visited once a month; $7.8 \%(n=10)$ once every 3 months; $11.6 \%(n=15)$ once every 6 months or less; $38.0 \%(n=49)$ answered that they did not visit.

Finally, regarding the monthly expenditure on DSEA, of those who were currently using it $(n=77)$ it was observed that $52 \%(\mathrm{n}=40)$ spent up to $\$ 37.6$ American dollars (\$) - data also shown according to the average price of a cup of coffee in Miami (US.) $=\$ 3.9^{30}$ (9.5 cup of coffees); 34\% ( $n=26)$ between $\$ 37.8$ (9.5 cup of coffees) and $\$ 75.3$ (19.1 cup of coffees); 13\% ( $n=10)$ between $\$ 75.5$ (19.2 cup of coffees) and $\$ 150.6$ (38.3 cup of coffees), and $1 \%(n=1)$ above $\$ 188.3$ (47.9 cup of coffees). Our data collection was in the year 2017. This year the minimum wage in Brazil was $\$ 177.1$ (45.0 cup of coffees).

\section{DSEA Knowledge}

The participants' knowledge about DSEA use was evaluated by the questions:

1. Ergogenic effects are any and all mechanisms, physiological, nutritional or pharmacological effects that are capable of improving performance in physical, sports or even occupational activity. Is that correct for you? (Right answer is YES), approximately $60 \%(n=77)$ were unable to answer; $1.6 \%(\mathrm{n}=2)$ answered no, and $38 \%(\mathrm{n}=50)$ answered yes.

2. Nutritional supplements are preparations designed to complement the diet and provide nutrients, such as vitamins, minerals, fibers, fatty acids or amino acids, which may be lacking or cannot be consumed in sufficient quantities in a person's diet. Is that correct for you? (Right answer is YES), 91.4\% $(n=118)$ answered yes; 3.1\% $(n=4)$ answered no and $5.4 \%(n=7)$ did not know how to answer.

3. To achieve my aesthetic and physical and sporting performance goals, I would take supplements, even if that would put my health and quality of life at risk. For you, this statement is:. (...) The majority, 83.7\% $(n=108)$ said that this statement is "absolutely false"; $8.5 \%(\mathrm{n}=11)$ said that it is "partially false"; $6.2 \%(\mathrm{n}=8)$ which is "partially true" and only $1.6 \%(\mathrm{n}=2)$ said it is "true". 
Table 4 Types of Dietary Supplements and Ergogenic Aids (DSEA) Reported and Used by the Sample of RT Practitioners Evaluated, $n=129$

\begin{tabular}{|l|l|l|}
\hline DSEA Type & $\mathbf{n}$ & $\%$ \\
\hline Whey protein & 66 & 51.1 \\
Branched chain amino acids & 48 & 37.2 \\
Vitamins & 34 & 26.3 \\
Creatine & 20 & 15.5 \\
Caffeine & 20 & 15.5 \\
Glutamine & 19 & 14.7 \\
Hypercaloric & 14 & 10.8 \\
Thermogenic & 14 & 10.8 \\
Multivitamin & 14 & 10.8 \\
Albumin & 11 & 8.5 \\
Carb-up & 9 & 6.9 \\
Dextrose & 9 & 6.9 \\
Energy bars & 7 & 5.4 \\
Isotonic & 6 & 4.6 \\
Energetic & 6 & 4.6 \\
Antioxidant complex in capsules & 6 & 4.6 \\
Maltodextrin & 5 & 3.8 \\
Hydrolyzed meat protein & 5 & 3.8 \\
Casein & 5 & 3.8 \\
Collagen & 4 & 3.1 \\
Tribulus terrestris & 4 & 3.1 \\
Shakes & 4 & 3.1 \\
Anti-inflammatory & 3 & 2.3 \\
Anabolic steroid & 3 & 2.3 \\
Carnitine & 3 & 2.3 \\
Conjugated linoleic acid & 2 & 1.5 \\
Omega-3 & 2 & 1.5 \\
Coconut oil - in capsule & 1 \\
Prohormonal & 1 & 0.7 \\
\hline
\end{tabular}

\section{Possible Associations of DSEA Use with Variables of Interest}

There was no significant association between participant's sex and body mass index classification $\left(\mathrm{X}^{2}=7.488, \mathrm{p}=0.11\right)$, time of physical activity practice $\left(\mathrm{X}^{2}=1.917, \mathrm{p}=0.75\right)$, educational levels $\left(\mathrm{x}^{2}=8.989, \mathrm{p}=0.25\right)$, and marital status $\left(\mathrm{X}^{2}=4.809, \mathrm{p}=0.30\right)$. In addition, there was no significant association between participant's sex and the usage of DSEA $\left(X^{2}=2.136, p=0.14\right)$. Also, there was no significant association between the usage of DSEA and marital status $\left(X^{2}=3.646, p=0.45\right)$, educational level $\left(X^{2}=9.914, p=0.19\right)$, socioeconomic class $\left(\mathrm{X}^{2}=10.362, \mathrm{p}=0.06\right)$.

\section{Discussion}

The main aim of the present study was to obtain a profile of DSEA use among recreational Brazilian RT practitioners. Our findings were that $77 \%(\mathrm{n}=99)$ declared that they had already used DSEA and $79 \%$ said they believed in their effectiveness. The majority (53\%) sought information over the internet and 39\% through a dietitian/ nutritionist. It should be noted that $24.2 \%$ ingested DSEA with the guidance of a Physical Education Professional/ Personal trainer, which is not ethical or appropriate. As for the number of DSEA used, $50.5 \%$ used up to two types. Whey Protein (66\%) was the most used followed by BCAAs (48\%). As for the sociodemographic profile $34.9 \%$ were from class B2 and 39\% had completed high school. A point to be highlighted was that there was no association between the variables of interest (sex, body mass index, physical activity practice, educational level, marital status, and socioeconomic level) and the factors of DSEA use.

El Khoury and Antoine-Jonville ${ }^{28}$ evaluated the use of DSEA among Beirut gyms attendees. The intake of nutritional supplements was reported by $36.3 \%$ of the participants and with a low presence of medical supervision. Men and beginners used more DSEA associated with improving physical performance and muscle strengthening; while women, older people and more experienced practitioners were more concerned with health-promoting products (vitamins and minerals). The authors suggested that the adequate dissemination of accurate and scientifically based information on the benefits and side effects of nutritional supplements is highly recommended in the gym environment. Bianco et $\mathrm{al}^{15}$ evaluated DSEA intake by exercisers (in the suburbs and center) in the city of Palermo (Italy) and observed that protein consumption was the most frequent, with similar prevalence in both groups $(30 \%$ for exercisers in the center and $28.8 \%$ in the suburbs of the city). Wardenaar et $\mathrm{al}^{24}$ evaluated the prevalence of DSEA use by Dutch competitive athletes $(\mathrm{n}=778)$. Among them, $97.2 \%$ used DSEA at some point in their sports career. Among the DSEAs used without guidance in the last month, the use of multivitamins and minerals $(42.9 \%)$, isotonic drinks (44.1\%), and caffeine $(13.0 \%)$ was reported. Dietary counseling was associated with a higher prevalence of vitamin $\mathrm{D}$, isotonic protein drinks, energy bars, dextrose, beta-alanine, and sodium bicarbonate use. Dietary counseling was inversely associated with the use of multivitamins, calcium, vitamin $\mathrm{E}$ and B, energy drinks, and BCAA. Therefore, receiving dietary counseling seems to result in more appropriate choices regarding DSEA use related to physical performance, physical recovery and health. 
Goston and Correia ${ }^{1}$ observed that $36.8 \%$ of exercisers in the city of Belo Horizonte (southeast region of Brazil) reported taking DSEA. The highest intake was among men (44.6\%) and proteins and amino acids were the most used supplements (58\%). The majority (55\%) reported the use of supplements without specialized professional guidance and relied on self-prescription. Individuals under 30 years, mainly men, took protein-rich supplements and older participants reported taking supplements rich in vitamins, minerals and herbal medicines. In our study, $36.3 \%$ of the users reported that the dietitian was responsible for the prescription, $23.2 \%$ relied on self-prescription, $24.2 \%$ used it under the guidance of a personal trainer physical, $9.1 \%$ with medical advice, $3 \%$ followed the prescription of a seller from supplement store, $3 \%$ under the guidance of a training colleague and $1 \%$ under the guidance of a beautician. Our results are worrying since the professional responsible for the prescription and guidance should be the dietitian, according to regional laws.

It should be noted that the results of the present study corroborate similar studies carried out in Brazil. Santos and Santos $^{31}$ in a research carried out in Vitória-ES observed that the relative frequency of DSEA use was $70 \%$. Hirschbrusch et $\mathrm{al}^{32}$ found values of $61 \%$ and Gomes et $\mathrm{al}^{33}$ in a survey conducted in Ribeirão PretoSP found $52.7 \%$. In the study by Linhares and Lima, ${ }^{34}$ the prevalence of DSEA use by RT practitioners in the gyms of Campos dos Goytacazes-RJ was $65 \%$. We found the predominance of proteins as the DSEA most used by recreational RT practitioners. This corroborates the findings of Theodoro et al. ${ }^{35}$ Araújo et al. ${ }^{36}$ Goston and Correia $^{1}$ and Linhares and Lima, ${ }^{34}$ who found $81 \%$, $49 \%, 69 \%$, and $78 \%$ respectively, for the predominance of protein supplements.

Despite most interviewees affirmed having had information on the topic, the main problem is the source of this information. Most respondents searched the internet (53\%) and friends (30\%). Only 39\% sought to obtain information from a dietitian. Domingues and Marins, ${ }^{37}$ Costa and Rogatto $^{38}$ and Pamplona et al ${ }^{39}$ also reported a low frequency of consultation with a specialized professional $(36 \%, 13$ and $22.2 \%$, respectively). Furthermore, we are surprised by the fact that $22 \%$ of supplement users in the present study seek out physical education professionals to recommend them.

Navarro and Araújo ${ }^{40}$ and Araújo et al ${ }^{36}$ highlight that the dietitian is usually consulted for supplements prescription. However, other studies reported that other professionals and unqualified sources are also consulted by users, such as physical education professionals/instructors, friends or even self-prescribing. ${ }^{41-44}$

Another point to highlight is the low quality of information provided in gyms. Mettler et $\mathrm{al}^{23}$ observed that the high prevalence of supplement intake among users of Swiss gyms was associated with a low level of information quality. In a recent study, Ruano and Teixeira ${ }^{45}$ concluded that gyms attendees in Portugal are major consumers of dietary supplements. The biggest users are men and young people who use powdered protein supplements to increase muscle mass who get information from accredited nutritionists and consider themselves well informed and buy supplements online. AlRuthia et $\mathrm{al}^{46}$ warn that public health campaigns are needed to educate the public about the potential harmful effects of DSEA if purchased from unofficial providers or ingested without consulting qualified professionals.

An important aspect assessed in our study are the expenses with DSEA. There are important issues: people spend on ineffective strategies and something that might be bad for their health.

\section{Study Strengths and Limitations}

The strengths of our study are that it involved different regions of the State of Espírito Santo which is an important state in the Southeast region of Brazil with approximately 4 million inhabitants. Our results involved municipalities that were not previously studied about the use of DSEA. One limitation is the difficulty in obtaining accurate answers when the research tools are questionnaires due to the presence of subjectivity bias. On the other hand, questionnaires are the instruments with the largest and easiest access and low cost, which is a real advantage. Another limitation is that the assessment through a questionnaire necessarily needs large samples to draw more accurate scenarios. In our case, a sample with more than 100 people is relatively considerable, as we assess an audience with specific characteristics, that is, practitioners of regular exercise and RT. In addition, questionnaire studies are relatively effective as pilot and initial studies and easy to access and execute and reproduce. Although our tool has not been validated, it underwent an evaluation by experts (one of the validation phases) and may have greater ecological validity because it was designed specifically for the target audience. To search for possible associations between variables of interest, one of the ways would be to evaluate more expressive samples in terms of number of people and range of different profiles. 


\section{Conclusion}

Our study evaluated the use of DSEA among recreational Brazilian RT practitioners (before 2019 coronavirus pandemic) and found that DSEA use is highly prevalent, especially protein supplements. Most users obtained information about DSEA from the internet. Thus, the necessity of an appropriate attitude and orientation by health professionals working with RT practitioners was highlighted. Also, attention should be paid to the quality of information in social networks, website, and the internet in general. It is relevant that health professionals help RT practitioners with correct information and guidance so that practitioners can develop an appropriate attitude towards DSEA use as well as reflect on whether this use would be appropriate. For these people, this information is important because most DSEA used do not have robust scientific evidence as to its safety and effectiveness. Finally, if it is necessary to use DSEA to meet a nutritional need or for health reasons, it is essential that health professionals help RT practitioners in choosing tested and safe products.

\section{Institutional Review Board Statement}

The study was conducted according to the guidelines of the Declaration of Helsinki, and was approved by the Research Ethics Committee of the Federal University of Espírito Santo (CAAE: 63228215.1.3001.5505). Informed consent was obtained from all subjects involved in the study.

\section{Acknowledgment}

The authors thank the volunteers who dedicated part of their time to participate in the present study. RLV is a productivity fellowship at the Espírito Santo Research and Innovation Support Foundation (FAPES) agency (Public Notice No 18/2018-Bolsa Researcher Capixaba).

\section{Author Contributions}

All authors made a significant contribution to the article, whether in conception, study design, execution, data acquisition, analysis and interpretation. In addition, everyone participated in the writing, in the critical review of the article; gave final approval of the version to be published; and agreed with the Journal to which the article was submitted and are responsible for all aspects of the research.

\section{Funding}

There is no funding to report.

\section{Disclosure}

The authors declare no conflicts of interest.

\section{References}

1. Goston JL, Correia MI. Intake of nutritional supplements among people exercising in gyms and influencing factors. Nutrition. 2010;26(6):604-611. doi:10.1016/j.nut.2009.06.021

2. Erdman KA, Fung TS, Reimer RA. Influence of performance level on dietary supplementation in elite Canadian athletes. Med Sci Sports Exerc. 2006;38(2):349-356. doi:10.1249/01.mss.0000187 332.92169.e0

3. Huang S-H, Johnson K, Pipe AL. The use of dietary supplements and medications by Canadian athletes at the Atlanta and Sydney Olympic Games. Clin J Sport Med. 2006;16(1):27-33. doi:10.1097/01. jsm.0000194766.35443.9c

4. Scofield DE, Unruh S. Dietary supplement use among adolescent athletes in central Nebraska and their sources of information. J Strength Conditioning Res. 2006;20(2):452. doi:10.1519/R-16984.1

5. Palmer ME, Haller C, McKinney PE, et al. Adverse events associated with dietary supplements: an observational study. Lancet. 2003;361 (9352):101-106. doi:10.1016/S0140-6736(03)12227-1

6. Rocha L, Pereira M. Consumo de suplementos nutricionais por praticantes de exercícios físicos em academias. Revista Nutrição. 1998;v (11):76-82.

7. Sobal J, Marquart LF. Vitamin/mineral supplement use among high school athletes. Adolescence. 1994;29(116):835-843.

8. Striegel H, Simon P, Wurster C, Niess A, Ulrich R. The use of nutritional supplements among master athletes. Int J Sports Med. 2005;27(03):236-241. doi:10.1055/s-2005-865648

9. Morrison LJ, Gizis F, Shorter B. Prevalent use of dietary supplements among people who exercise at a commercial gym. Int J Sport Nutr Exerc Metab. 2004;14(4):481-492. doi:10.1123/ijsnem.14.4.481

10. Gillen JB, Trommelen J, Wardenaar FC, et al. Dietary protein intake and distribution patterns of well-trained Dutch athletes. Int J Sport Nutr Exerc Metab. 2017;27(2):105-114. doi:10.1123/ijsnem.2016-0154

11. Aljaloud SO, Ibrahim SA. Use of dietary supplements among professional athletes in Saudi Arabia. J Nutr Metab. 2013;2013:1-7. doi: $10.1155 / 2013 / 245349$

12. Wolfe RR. Protein supplements and exercise. Am J Clin Nutr. 2000;72(2):551S-557S. doi:10.1093/ajen/72.2.551S

13. Wardenaar F, van den Dool R, Ceelen I, Witkamp R, Mensink M. Self-reported use and reasons among the general population for using sports nutrition products and dietary supplements. Sports. 2016;4 (2):33. doi:10.3390/sports4020033

14. Greger JL. Dietary supplement use: consumer characteristics and interests. $J$ Nutr. 2001;131(4 Suppl):1339S-43S.

15. Bianco A, Mammina C, Thomas E, et al. Protein supplementation and dietary behaviours of resistance trained men and women attending commercial gyms: a comparative study between the city centre and the suburbs of Palermo, Italy. J Int Soc Sports Nutr. 2014;11:30. doi:10.1186/1550-2783-11-301550-2783-11-30

16. Bianco A, Mammina C, Paoli A, et al. Protein supplementation in strength and conditioning adepts: knowledge, dietary behavior and practice in Palermo, Italy. J Int Soc Sports Nutr. 2011;8(1):25. doi:10.1186/1550-2783-8-251550-2783-8-25

17. Kaufman DW, Kelly JP, Rosenberg L, Anderson TE, Mitchell AA. Recent patterns of medication use in the ambulatory adult population of the United States: the Slone survey. JAMA. 2002;287(3):337. doi:10.1001/jama.287.3.337 
18. Knapik JJ, Steelman RA, Hoedebecke SS, Austin KG, Farina EK, Lieberman HR. Prevalence of dietary supplement use by athletes: systematic review and meta-analysis. Sports Med. 2016;46 (1):103-123. doi:10.1007/s40279-015-0387-7

19. Rockwell MS, Nickols-Richardson SM, Thye FW. Nutrition knowledge, opinions, and practices of coaches and athletic trainers at a division I university. Int J Sport Nutr Exerc Metab. 2001;11 (2):174-185. doi:10.1123/ijsnem.11.2.174

20. Harrison RA, Holt D, Pattison DJ, Elton PJ. Are those in need taking dietary supplements? A survey of 21923 adults. Br J Nutri. 2004;91 (4):617-623. doi:10.1079/BJN20031076

21. Maughan R. Contamination of dietary supplements and positive drug tests in sport. J Sports Sci. 2005;23(9):883-889. doi:10.1080/ 02640410400023258

22. Di Luigi L. Supplements and the endocrine system in athletes. Clin Sports Med. 2008;27(1):131-151. doi:10.1016/j.csm.2007.09.003

23. Mettler S, Bosshard JV, Häring D, Morgan G. High prevalence of supplement intake with a concomitant low information quality among Swiss fitness center users. Nutrients. 2020;12(9):2595. doi:10.3390/ nu12092595

24. Wardenaar FC, Ceelen IJM, Van Dijk J-W, et al. Nutritional supplement use by Dutch elite and sub-elite athletes: does receiving dietary counseling make a difference? Int J Sport Nutr Exerc Metab. 2017;27 (1):32-42. doi:10.1123/ijsnem.2016-0157

25. Krumbach CJ, Ellis DR, Driskell JA. A report of vitamin and mineral supplement use among university athletes in a division I institution. Int J Sport Nutr. 1999;9(4):416-425. doi:10.1123/ijsn.9.4.416

26. Braun H, Koehler K, Geyer H, Kleinert J, Mester J, Schänzer W. Dietary supplement use among elite young German athletes. Int J Sport Nutr Exerc Metab. 2009;19(1):97-109. doi:10.1123/ ijsnem.19.1.97

27. ADA. Practice paper of the dietary reference intakes. American Dietetic Association: dietary supplements. J Am. 2005;105(3):461-470.

28. El Khoury D, Antoine-Jonville S. Intake of nutritional supplements among people exercising in gyms in Beirut city. J Nutr Metab. 2012;2012:703490. doi:10.1155/2012/703490

29. APEB. Associação Brasileira das Empresas de Pesquisa (ABEP). Critério Padrão De Classificação Econômica Brasil; 2008.

30. Yahoo Finance. The Price of a Cup of Coffee Around the World. 2021. Available from: https://finance.yahoo.com/news/price-cupcoffee-around-world-200000584.html. Accessed August 15, 2021 ..

31. Dos Santos MÂA, Dos Santos RP. Use of alimentary supplements as form of improving the performance in the programs of physical activity in gymnastic academies. Revista Paulista De Educação Física. 2002;16 (2):174. doi:10.11606/issn.2594-5904.rpef.2002.138710

32. Hirschbruch M, Fisberg M, Mochizuki L. Consumo de suplementos por jovens freqüentadores de academias de ginástica em São Paulo. Revista Brasileira Medicina Do Esporte. 2008;14(6):539-543.

33. Gomes GS, Degiovanni GC, Garlipp MR, Chiarello PG, Jordão Junior AA. Caracterização do consumo de suplementos nutricionais em praticantes de atividade física em academias. Medicina. 2008;41 (3):327-331. doi:10.11606/issn.2176-7262.v41i3p327-331
34. Linhares T, Lima R. Prevalência do uso de suplementos alimentares por praticantes de musculação nas academias de Campos dos Goytacazes/RJ. Revista Vértices. 2006;8(1):101-122. doi:10.19180/ 1809-2667.20060008

35. Theodoro H, Ricalde S, Amaro F. Avaliação nutricional e autopercepção corporal de praticantes de musculação em academias de Caxias do Sul - RS. Revista Brasileira De Medicina Do Esporte. 2009;15(4):291-294.

36. de Araújo LR, Andreolo J, Silva MS. Utilização de suplemento alimentar e anabolizante por praticantes de musculaçäo nas academias de Goiânia-GO. Braz J Sci Movement. 2002;10(3):13-18. doi:10.18511/rbcm.v10i3.457

37. Domingues S, Marins J. Utilização de recursos ergogênicos e suplementos alimentares por praticantes de musculação em Belo Horizonte - MG. Fitness e Performance J. 2007;6(4):218-226.

38. Costa H, Rogatto G. Consumo de suplementos alimentares em homens jovens praticantes de musculação em academias de Cuiabá. Revista Brasileira De Ciência e Movimento. 2006;14:4.

39. Pamplona P, Souza J, Oliveira F, Machado L, Oliveira R. Perfil dos consumidores de suplemento em praticantes de musculação de Florianópolis. Revista Brasileira De Ciência Do Movimento. 2005;13(4):153.

40. Navarro F, Araújo M. Consumo de suplementos nutricionais por alunos de uma academia de ginástica, Linhares - ES. Revista Brasileira De Nutrição Esportiva. 2008;2(8):46-54.

41. Navarro F, Alves S. O uso de suplementos alimentares por frequentadores de uma academia de Potim - SP. Revista Brasileira De Nutrição Esportiva2010. 2010;4(20):139-146.

42. Navarro A, Freitas A, Oliveira C, Santos H. Consumo de suplementos alimentares por praticantes de exercício físico em academias de bairros nobres de Recife. Revista Brasileira De Nutrição Esportiva. 2013;7(40):204-211.

43. Souza R, Ceni G. Uso de suplementos alimentares e autopercepção corporal de praticantes de musculação em academias de Palmeira das Missões - RS. Revista Brasileira De Nutrição Esportiva. 2014;8 (43):20-22.

44. Schneider C, Machado C, Laska S, Liberali R. Consumo de suplementos nutricionais por praticantes de exercício físico em academias de musculação de Balneário Camboriú - SC. Revista Brasileira De Nutrição Esportiva. 2008;2(11):307-322.

45. Ruano J, Teixeira VH. Prevalence of dietary supplement use by gym members in Portugal and associated factors. J Int Soc Sports Nutr. 2020;17(1):11. doi:10.1186/s12970-020-00342-z

46. AlRuthia Y, Balkhi B, Alrasheed M, et al. Use of dietary and performance-enhancing supplements among male fitness center members in Riyadh: a cross-sectional study. PLoS One. 2018;13(6): e0199289. doi:10.1371/journal.pone.0199289

\section{Publish your work in this journal}

Open Access Journal of Sports Medicine is an international, peerreviewed, open access journal publishing original research, reports, reviews and commentaries on all areas of sports medicine. The manuscript management system is completely online and includes a very quick and fair peer-review system. Visit http://www.dovepress. com/testimonials.php to read real quotes from published authors. 